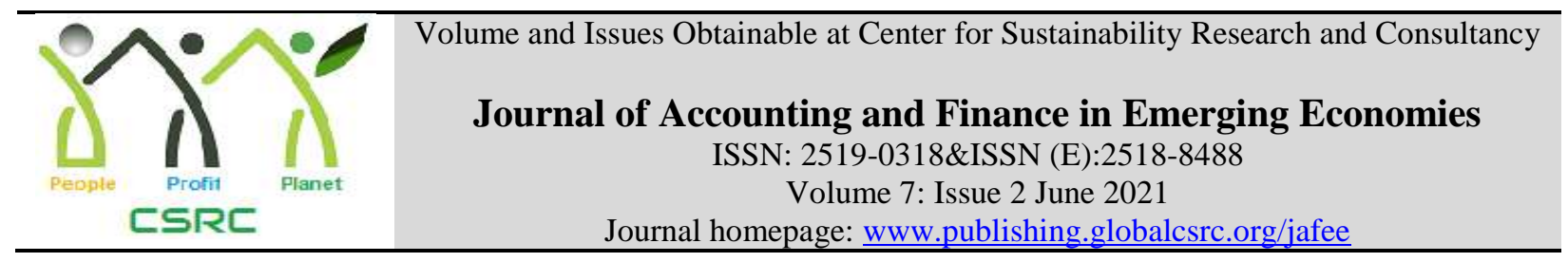

\title{
Pakistan's Growth Empirics and Foreign Direct Investment: An Assessment of the Role of Domestic Financial Sector
}

Noreen Safdar, Assistant Professor, Department of Economics, The Women University Multan, Pakistan

Ruqia Shaheen, Lecturer, Department of Economics, National University of Modern Languages Islamabad (Multan Campus), Pakistan

Fouzia Yasmin, Lecturer, Department of Economics, University of Sahiwal, Pakistan

Naureen Afzal, Lecturer, Institute of Management Sciences, The Women University Multan,

Pakistan

*Corresponding author's email address: Fouziayasmin@ uosahiwal.edu.pk

\section{ARTICLE DETAILS \\ History \\ Revised format: May 2021 \\ Available Online: Jun 2021}

\begin{tabular}{l} 
Keywords \\
Financial Development, \\
Economic growth, Foreign \\
Direct Investment, Inclusive \\
Growth \\
\hline
\end{tabular}

JEL Classification

M40, M41

\begin{abstract}
Purpose: This research endeavours to investigate the role of fiancial sector in determining the foreign direct inflows in pakistan.
\end{abstract}

Design/Methodology/Approach: Autoregressive Distributed Lag Model is applied to conclude the nature of linear association among the variables, in this study, we have used time series data over the period 1980-2019 of Pakistan. A financial development index has been created to illustrate the financial development by using Principle Component Analysis (PCA). Robustness of the relation among variables is also checked, and incorporated this in the empirical model. Findings: The findings described very interesting implications, by exhibiting a positive association among FDI and economic growth in the presence of financial sector indicators. These conclusions hold notwithstanding in the presence or absence of Financial development Index. Therefore, the presence of strong financial sector is necessary to attract FDI and to smoothen the economic growth process.

Implications/Originality/Value: The role of fiancial sector is indespensible in determining the economic activity. In addition to this, research at hand explore the inclusive nature of the relationships among foreign direct investment (FDI), Financial sector, and economic growth. It exhibits a reflection of the various sources of economic growth.

(C) 2021 The authors, under a Creative Commons Attribution-

NonCommercial 4.0

\footnotetext{
Recommended citation: Safdar, N., Shaheen, R., Yasmin, F. and Afzal, N. (2021). Pakistan Growth Empirics and Foreign Direct Investment: An Assessment of the Role of Domestic Financial Sector. Journal of Accounting and Finance in Emerging Economies, 7 (2), 365 375
} 


\section{Introduction}

Foreign direct investment is an essential portion of an effective and open international system of economy and the main motivation for economic development. However, the advantages of foreign direct investment are not consistent through countries, sectors, and local societies (Liang et al., 2021). National policies are a matter of international investment for captivating foreign direct investment. Foreign direct investment (FDI) has developed significantly as the main sYstem of capital transfer internationally. In past, the foreign capital flight has been moving towards the developed (Vernon 1966) while the transfer has turned towards the deeloping countries (Hussain et al., 2021). One must have anticipated variations in national competitive benefits to be reflected in additional sustainable developments. Seemingly, to scope that any developments occur rapidly (Gao, 2004).

Most of the developing countries depend essentially on foreign direct investment as it provides a basis to finance at an external level, for the reason behind that foreign direct investment energizing growth of the economy more rapidly (Ibrahim et al., 2021) specifically, Foreign direct investment is assumed to be rarely unbalanced in the allocation of technology, financial assets, managerial skills, and market access. financial assets are mostly applied to expand the capacity of production through accumulative fixed investment, while technological transformation along with the skills develops creative ability. Foreign direct investment also increases domestic pressures for domestic firms that result in augmenting allocative productivity and technical proficiency in the recipient country of the FDI.

Like Other developing countries, FDI flows are increasing in Pakistan, as being an important instrument of growth, in addition to this variation of growth-oriented policies in the financial sector that are compatible for foreign and local depositors, the more the chance to attract foreign direct investment as technology, capital source, market access, and managerial skills for the development of the economy. The economy of Pakistan offers the capability for placing business, and foreign investment is completely secure through Law, as well as escaping double taxes. The interanational management policies deliberated through the government for captivating supplementary foreign direct investment has been attracted by accepting policies relating to denationalization and deregulation of economic movement and better reliance on market powers in the country.

\section{Literature Review}

Uddin and Aziz (2o14) tried to found the part of public investment in the process of economic growth to the BangIadesh economy. Time series data was obtained from 1972-2o11. Research used to co-integration test and Granger Causality to examine the reIationship between variabIe. It used GDP as dependent variabIe and gross formation and public investment as independent variabIes. It argues that Public Investment had positive effects upon economic growth. When public investment enhance, economic growth aIso increased and wiII cause economic deveIopment in future days. Here, it shouId be highlighted that deveIoped infrastructure and skiIIed Iabour and poIiticaI stability was need for standard IeveI of ImpIementation of public investment. It was Suggested that excessive public investment IeveI with institutionaI sector boost up in BangIadesh because it is favourabIe for economy. Azam and Ahmed (2o15) discussed effect of human capitaI and foreign direct investment upon economic growth. He studies the deveIoped countries from 1993-2o11 and used Iiner regression techniques to used the fixed-effect and random-effects modeI. In the host countries, FDI facilitate and provided better politicaI environment, business polices and potentiaI investors. Foreign direct investment and human capitaI were an important and positive effect on Gross Domestic Product. He recommended that the policy maker must do in favour of deveIopment in economic growth, domestic investment must be made better and the sector of heaIth and education IeveI must be improved. And improve the domestic investment so that enhance the FDI infIow. 
Ilegbinosa et al. (2015) indicated that effect of domestic investment on growth of economy by applying time series data from 197o-2o13. It was used MuItipIe Regression and co-integration technique to examine the reIationship of the variabIes. This study divided into two government expenditure; productive and protective expenditure and found the effect of investment upon the private investment. They emphasized that private investment had optimistic and insignificant effect on growth of economy as the same time government investment had adverse and insignificant influence on growth of economy. They suggested that impIementation of budge shouId improve.

Sothan (2o15) examined that the causaI influence of FDI and exports upon growth of economy Over period 1980 to 2013 and observed 21 countries, using the paneI co-integration and Granger causaIity. Outcome showed that there was Iong term steady-state correspondence among foreign direct investment, exports and GDP for the countries. There was found bidirectionaI causality between foreign direct investment and GDP in the Iong term. Foreign direct investment and exports were affected upon growth of Iong-run in the countries. Further government shouId facilitate politicaI and economic stability, improve infrastructure, abolish aII hurdIes that connect with the foreign direct investment and encourage the financiaI sector.

Agrawal (2015) focused on correIation among foreign direct investmnet and economic growth. It was applied paneI data from 1989-2o12, used oIS (Ordinary Ieast square) method and cOintegration method were used. VariabIes were used FDI, gross domestic product and growth of economy. It was founded bidirectionaI causality among FDI and growth of economy. Hussain and Haque (2o16) indicated that there was reIationship among FDI, trade, and GDP for the economy of BangIadesh used the annual time series data for time span 1973 to 2o14. By using Vector Error Correction ModeI (VECM), that there was Iong run correspondence among these variabIes. The foreign investment variabIes and trade had significant effect upon the GDP per capita.

Makuyana and odhiambo (2o16) focused on the empiricaI evidence of public and private investment was important factor for economic growth of both deveIoped and deveIoping countries. It was used cross-sectionaI data that contain the sampIe of 24 countries. Pubic investment was very important for deveIoped countries and focused on basic infrastructure caused private investment. In deveIoping countries public and private investment were very significant but private investment more appropriate than public investment. And focused on the infrastructure that enhance the private investment. SoIomon (2o17) estimated that, in the host counties, how position of economic growth, human capitaI, financiaI deveIopment and economic and poIiticaI environment had concurrent affected the FDI upon economic growth. It was used generalization methods of movements (GMM) with paneI data from 1981-20o5 of 111 countries. It was considered that FDI a way of technoIogy in the host country from another country. Further, FDI had marginaI effect upon economic growth was significant beyond a maximum point where the negative impact the quality of politicaI environment, factor are constant. Outcomes expIained that the position of economic deveIopment, human capitaI and politicaI environment had significant impact the reIationship between foreign direct investment and growth.

Mohamed et aI (2o17) focused on the casuaI correspondence among FDI, domestic investment and economic growth in MaIaysia. It was collected the data from 197o-2oo8 and estimated the reIationship of variabIes. It was applied Vector Auto-regression method. They used the independent variable were FDI, value of export, human capitaI deveIopment and reaI gross fixed capitaI formation and GDP as dependent variabIes. Outcomes were advocated, in the Iong run, that causality between economic growth and domestic investment and no causality among 
FDI and economic development. On Other side, FDI was crowded-in impact domestic investment in short run. Ameer and Xu (2o17) approximated the influence of FDI upon growth of economy from the era 20o5-2o14. He used ordinary Ieast square (OIS) and generalization method of moments (GMM) modeI. It was used gross capitaI formation, gross domestic savings, trade, infIation proxy variabIes for modeI estimation. Outcome was displayed that FDI OutfIow and infIow impression on growth of economy had positive and significant. His suggestion is for government to use significant techniques by which economic growth must be improved.

FaisaI, Muhammad and Tursoy (2o17) used the auto regression distributed Iag approach (ARDL) Over the period 1999-2o15. And estimated the co-integration approach was applied time series data. He was focused on the reIationship among GDP, foreign direct investment and domestic credit. Finding shows that, in the Iong run, stock prices had positive impact on foreign direct investment and financiaI deveIopment had negative effect on foreign direct investment. ResuIts showed that if the government pIay significant role in the fIOw Of FDI then economy can move towards development and growth. Bakari (2o17) took annuaI time series data FOR DURATION OF 196o-2o15. Test was applied correIation analysis vector error correction modeI (VECM) and Granger causality test. ReIationship was observed domestic investment and growth of economiy in MaIaysia. In Iong run, it was positiveIy impact beTween domestic investment, export and Iabour upon growth of economy. In the short run, there was no reIationship between domestic investment and growth of economy. He investigated economic policies of so many countries Iike India, china and Pakistan.

\section{Data and Methodology}

\section{a) Data Sources}

Thisuse dthe time series data of foreign direct investment, and analysed the role of domestic financial sector for Pakistan economy. This study used yearIy time series data which covered the time period 1980-2019. The data of gross domestic product (GDP), inflation rate, and worker remittance, financiaI deveIopment taken from worId deveIopment index, trade openness, Iabour force, manufacturing sector growth rate, exchange rate have been used ofr empirical analysis.

\section{b) Model Specification}

In this part we discuss the modeI specification of this study. We used two modeIs to empirically analyse the problem statement. We analysis the Pakistan's economy hypothesis through cointegration inference differentiate Iike Auto regressive distributed Iag (ARDI) method.

\section{c) ModeI One: Economic Growth and Foreign Direct Investment}

The modeI we expIain growth of economy and FDI and macroeconomic variabIes in our research.

$$
\begin{gathered}
G D P=f(F D I, I N F, T O, W R) \\
G D P=\beta o+\beta 1(F D I)+\beta 2(I N F)+\beta 3(W R)+\beta 4(T O)+\varepsilon
\end{gathered}
$$

\section{ARDL form of model 1}




$$
\begin{aligned}
\Delta G D P_{t}=\mu_{0} & +\sum_{i=1}^{p} \mathrm{~V}_{i} \Delta G D P_{t-i}+\sum_{i=1}^{p} \pi_{i} \Delta F D I_{t-i}+\sum_{i=1}^{p} \omega_{i} \Delta T O_{t-i} \\
& +\sum_{i=1}^{p} \theta_{i} \Delta W R_{t-i}+\sum_{i=1}^{p} \vartheta_{i} \Delta I N F_{t-i}+\sigma_{1} G D P_{t-1}+\sigma_{2} F D I_{t-1} \\
& +\sigma_{3} W R_{t-1}+\sigma_{4} I N F_{t-1}+\sigma_{5} T O_{t-1}+\mu_{1 t}
\end{aligned}
$$

\section{d) ModeI Two: FinanciaI Sector and Growth Rate}

$$
\begin{gathered}
G D P=f(F D 4, W R, L F, M A N U, E X R) \\
G D P=\beta o+\beta 1(F D 4)+\beta 2(W R)+\beta 3(L F)+\beta 4(M A N U)+\beta 4(E X R)+\varepsilon
\end{gathered}
$$

ARDL form of model 2

$$
\begin{aligned}
& \Delta G D P_{t}=\mu_{0}+\sum_{i=1}^{p} \mathrm{~V}_{i} \Delta G D P_{t-i}+\sum_{i=1}^{p} \pi_{i} \Delta F D 4_{t-i}+\sum_{i=1}^{p} \omega_{i} \Delta W R_{t-i}+ \\
& \sum_{i=1}^{p} \quad \theta_{i} \Delta L F 2_{t-i}+\sum_{i=1}^{p} \quad \vartheta_{i} \Delta M A N U_{t-i}+\sum_{i=1}^{p} \vartheta_{i} \Delta E X R_{t-i}+\sigma_{1} G D P_{t-1}+ \\
& \sigma_{2} F D 4_{t-1}+\sigma_{3} W R_{t-1}+\sigma_{4} L F_{t-1}+\sigma_{5} M A N U_{t-1}+\sigma_{6} E X R_{t-1} \mu_{1 t}
\end{aligned}
$$

\section{Results and Discussion}

\section{a) Descriptive Analysis of the Data}

This segment deals through descriptive features of data. The analysis has been completed for all of the variables model one and model two separately in following.

Table 1: Descriptive Analysis

\begin{tabular}{cccccc}
\hline Variables & Mean & Median & Std.dev & Skewness & Kurtosis \\
\hline GDP & 678.729 & 2677.700 & 8563.900 & 1.427376 & 3.77034 \\
FDI & 70481.98 & 24327.10 & 97057.06 & 1.4742 & 4.00801 \\
INF & 8.40160 & 7.92108 & 3.802016 & 0.6623 & 3.8053 \\
TO & 24316.11 & 14593.70 & 20614.53 & 1.2079 & 3.50039 \\
WR & 50441.776 & 2389.05 & 5672.730 & 1.96713 & 6.29605 \\
FD4 & -0.9893 & -0.9797 & 0.09828 & 0.0439 & 2.14135 \\
LF & 48.1000 & 49.9000 & 12.4000 & -1.9966 & 7.58054 \\
MANU & 15.6204 & 15.8634 & 1.24379 & -0.03358 & 2.4612 \\
EXR & 48.0150 & 45.0467 & 30.42669 & 0.444102 & 1.93814 \\
\hline
\end{tabular}

Source: estimation by the author with E-views 9.

\section{b) Correlation Analysis of the Data}

The construction of oblique convinced below, checks pair wise correlation of selected sequence to make samples for this study.

Table 2: Correlation Analysis

\begin{tabular}{lllll}
\hline \multicolumn{5}{c}{ Model 1 } \\
\hline Variables & FDI & INF & TO & WR \\
\hline FDI & 1.00 & & & \\
INF & 0.41315 & 1.00 & & \\
TO & 0.5118 & 0.21211 & 1.00 & \\
\hline
\end{tabular}




\begin{tabular}{lcccccc}
\hline WR & $0 . .5619$ & 0.0313 & 0.9314 & 1.00 & \\
\cline { 2 - 5 } & \multicolumn{7}{c}{ Model 2 } \\
\hline Variables & GDP & FD4 & LF & MANNU & WR & EXR \\
\hline GDP & 1.00 & & & & \\
FD4 & 0.358 & 1.000 & & & & \\
LF & 0.024 & 0.1213 & 1.000 & & & \\
MANU & 0.674 & 0.3168 & 0.1056 & 1.000 & & \\
WR & 0.975 & 0.3309 & 0.2865 & 0.63821 & 1.000 & \\
EXR & 0.923 & 0.1313 & 0.2138 & 0.62955 & 0.857 & 1.000 \\
\hline
\end{tabular}

Source: estimation by the author with E-views 9

\section{c) Unit Root Test Analysis}

\section{Augmented Dickey -FuIIer Test (ADF)}

Dickey and fuIIer (1989) presented a test to verify the unit root in the data i.e. stationary or nonstationary of a time series. The method verify the data series as difference stationary or not (I(o) and I(1)). The test is essentiaI to make out the order of integration. The Iag time of these variables has been choosen with the Akaike Information Criteria (AIC), IM test and Schwartz Bayesian Criteria (SBC).

Table 3: Unit Root Test

\begin{tabular}{ccccc}
\hline Variables & Intercept & $\begin{array}{c}\text { Intercept and } \\
\text { trend }\end{array}$ & None & Conclusion \\
\hline \multirow{2}{*}{ GDP } & -1.60041 & -3.75597 & -0.8284 & $\mathrm{I}(0)$ \\
& $(0.04718)$ & $(0.0314)$ & $(0.0349)$ & \\
FDI & -6.063218 & -7.73624 & -6.16251 & $\mathrm{I}(0)$ \\
INF & $(0.0000)$ & $(0.0000)$ & $(0.0000)$ & \\
& -3.72789 & -3.590076 & -3.6290 & $\mathrm{I}(0)$ \\
TO & $(0.004)$ & $(0.0034)$ & $(0.0004)$ & \\
& -4.557209 & -4.49528 & -4.6578 & $\mathrm{I}(0)$ \\
WR & $(0.0009)$ & $(0.0053)$ & $(0.004)$ & \\
& 0.7079 & -0.7756 & 1.1878 & $\mathrm{I}(1)$ \\
FD4 & $(0.0990)$ & $(0.0554)$ & $(0.0395)$ & $\mathrm{I}(0)$ \\
& -5.8742 & -3.5285 & -5.5873 & \\
LF & $(0.0000)$ & $(0.0043)$ & $(0.004)$ & $\mathrm{I}(0)$ \\
& -6.18870 & -6.08863 & -6.07887 & \\
MANU & $(0.0000)$ & $(0.0001)$ & $(0.0581)$ & $\mathrm{I}(1)$ \\
& -2.1703 & -4.49864 & -0.9697 & $\mathrm{I}(1)$ \\
\hline
\end{tabular}

than we applied Auto regressive distributed Iag (ARDI) test. In current study, the resuIt indicate the mixture of IeveI $\mathrm{I}(0)$ and I(1) series. Therefore, the Iong-run impact through the Auto regressive distributed Iag modeI and short run impact through the Error correIation modeI (ECM) is appropriate to apply.

\section{d) Bound Testing}


Table 5.3 establishes bound test assessment. The thumb rule of bound test is F-statistic is superior than upper bound value so, long run occurs in model, and value of F-statistic is decline upper bound than long run does not occur in model.

Table 3: Bound Testing for Co-integration

\begin{tabular}{llllll}
\hline & & \multicolumn{2}{l}{ At 5\% Significance level } & \multicolumn{2}{l}{ At 10\% Significance level } \\
\hline Models & F-Statistic & Lower bound & Upper bound & Lower bound & Upper bound \\
\hline Models 1 & 11.47813 & 2.56 & 3.49 & 2.2 & 3.09 \\
Models 2 & 8.54821 & 2.08 & 3.09 & 2.3 & 3.49 \\
\hline
\end{tabular}

Source: estimation by the author with E-views 9.

In model one F-value is 11.478 and upper bound value is 3.49 at $5 \%$ and upper bound value of 10 $\%$ is 3.09. In model two F-value is 8.54821 and upper bound value is 5 percent and 10 percent is 3.09 and 3.49. The conclusion displays that F-value is bigger than upper bound value of 5 percent and 10 percent. In model one long run relation occurs in it.

\section{Autoregressive Distributed IAG Model (ARDL)}

The usually used methodologies as EngIe-Granger (1987 )and Johansen-Juselius (199o) and Johansen $(1991 ; 1995)$ approaches. The main conclusion of ARDL method lies in its suppIeness that it can be worn while the variabIes are of different assembIe by Pesaran and Pesaran 1997 of integration. So, decIared prior to, the variabIes used in this study are a bIend of IeveI and $1^{\text {st }}$ difference. The test methods of co-integration based on Johansen (1991; 1995) Johansen-Juselius (199o) invoIve that every variabIes with comparabIe order of integration Iike $1^{\text {st }}$ difference. Therefore, these methods of co-integration are not appropriate and cannot work in this case. So, we execute the Auto regressive distributed Iag approached for co integration in this study.

\section{e) Long Run Analysis of Data}

The long run of assessment is explaining in this part by Auto regressive distributed lag model (ARDL). We applied two models and GDP applied dependent variable and all further variables like INF, FDI, WR LF, TO, EXR, MANU applied is independent variables.

Table 5: Long Run Analysis

\begin{tabular}{llll}
\hline & Model 1: & ARDL $(\mathbf{4 , 4 , 0 , 3 , 4 )}$ & ARDL $(\mathbf{3 , 2 , 4 , 4 , 4 , 4 )}$ \\
\hline Variable & $\begin{array}{l}\text { Coefficient } \\
\text { (P-value) }\end{array}$ & Variable & $\begin{array}{l}\text { Coefficient } \\
\text { (P-value) }\end{array}$ \\
\hline FDI & 0.04439 & FD4 & 3519.94 \\
& $(0.0000)$ & & $(0.0002)$ \\
INF & -7.66927 & LF & 17.6320 \\
& $(0.00003)$ & MANU & $(0.0005)$ \\
TO & 0.12750 & & 230.897 \\
& $(0.0155)$ & EXR & $(0.0100)$ \\
WR & 0.20819 & & -90.1198 \\
& $(0.0006)$ & & $(0.0400)$ \\
\hline
\end{tabular}

Source: estimation by the author with E-views 9.

Note: values in the parenthesis shows the respective probability values for the level of significance.

The model one is the independent variables is FDI and coefficient value is 0.0443 and there is statistically significant positively relation with Gross domestic product. The value foreign direct investment increase $1 \%$ in FDI that will increase in GDP by $0.04 \%$. The reason behind that the foreign direct investment enlarge than that Gross domestic product will also increase. The results support Zeb et al. (2013). Inflation rates the vector is -7.66 and inflation rate is negatively associated and statistically significant. The value of $1 \%$ rise in inflation that will increase in gross domestic product by $-7.66 \%$. Inflation is main issue of the Pakistan's economy. Our results support Naz et al. (2015), Nuri et al. (2012). Trade openness coefficient value is 0.127 and there 
significant and positive relationship with dependent variable. The value of trade openness is $1 \%$ increase in trade openness that will boost in the GDP by $0.12 \%$. The possible reason is trade openness is valuable for the growth of economics. Our result supports with the Falki (2009). The Worker remittance significantly related with Gross domestic product. It plays a role of protection in developing countries as well as Pakistan.

In the second model the independent variable is FD4 and coefficient value is 3519.94 and there is significant. The value of FD4 is $1 \%$ rise in FD4 that will rise in dependent variable of GDP by $3519.9 \%$. Financial sector plays a vital role in enhancing economic growth, for payments agreement financial sector support in expansion of the economy (Hussain, 2014). The variable labor force is 17.63 and the significant positively associated with GDP. The value of labor force is $1 \%$ increase in labor force that will increase in GDP by $17.63 \%$. Labor force and growth of economy were linked and it rise economic growth $5.6 \mathrm{Co}$-integration valuation of short run. The short run evaluation show that series amongst in short-run. The co-integration of short run feature should be important and necessity equivalent negative.

Short-Run Analysis

\begin{tabular}{|c|c|c|c|}
\hline \multicolumn{2}{|c|}{ Model I: ARDL (4,4,0,3,4) } & \multicolumn{2}{|c|}{ Model II:ARDL: $(3,2,4,4,4,4)$} \\
\hline Variable & $\begin{array}{l}\text { Coefficient } \\
\text { (P-value) }\end{array}$ & Variable & $\begin{array}{l}\text { Coefficient } \\
\text { (P-value) }\end{array}$ \\
\hline D(GDP(-1)) & $\begin{array}{r}-1.2237 \\
(0.000)\end{array}$ & $\mathbf{D}(\mathbf{W R})$ & $\begin{array}{r}0.01589 \\
(0.7282)\end{array}$ \\
\hline D(GDP(-2)) & $\begin{array}{l}-0.9910 \\
(0.005)\end{array}$ & D(WR(-1)) & $\begin{array}{r}-0.10803 \\
(0.0078)\end{array}$ \\
\hline D(GDP(-3)) & $\begin{array}{l}-0.51178 \\
(0.0029)\end{array}$ & $\mathbf{D}(\mathbf{W R}(-2))$ & $\begin{array}{l}0.01301 \\
(0.7184)\end{array}$ \\
\hline $\mathbf{D}(\mathbf{F D I})$ & $\begin{array}{c}0.0068 \\
(0.0001)\end{array}$ & D(FD4) & $\begin{array}{l}9297.64 \\
(0.0449)\end{array}$ \\
\hline D(FDI $(-1))$ & $\begin{array}{c}0.01424 \\
(0.000)\end{array}$ & D(FD4(-1) & $\begin{array}{l}3357.35 \\
(0.1354)\end{array}$ \\
\hline D(FDI $(-2))$ & $\begin{array}{l}0.01105 \\
(0.0001)\end{array}$ & $\mathbf{D}(\mathbf{L F})$ & $\begin{array}{r}-1.26702 \\
(0.8839)\end{array}$ \\
\hline D(INF) & $\begin{array}{c}48.6606 \\
(0.001)\end{array}$ & D(LF $(-1)$ & $\begin{array}{c}3.0554 \\
(0.7772)\end{array}$ \\
\hline D(TOT) & $\begin{array}{l}-0.6153 \\
(0.0001)\end{array}$ & $\mathbf{D}(\mathbf{L F}(-2)$ & $\begin{array}{l}-8.1156 \\
(0.4554)\end{array}$ \\
\hline D(TO(-1)) & $\begin{array}{c}0.0204 \\
(0.0001)\end{array}$ & D(MANU) & $\begin{array}{c}-93.58 \\
(0.3447)\end{array}$ \\
\hline D(TO(-2)) & $\begin{array}{c}-0.0613 \\
(0.000)\end{array}$ & D(MANU(-1) & $\begin{array}{c}0.2261 \\
(0.2735)\end{array}$ \\
\hline CoinEq(-1) & $\begin{array}{l}-0.43541 \\
(0.0000)\end{array}$ & D(MANU(-2)) & $\begin{array}{c}0.1457 \\
(0.6132)\end{array}$ \\
\hline & & D(EXR) & $\begin{array}{c}9.3641 \\
(0.7877)\end{array}$ \\
\hline & & $\mathbf{D}(\operatorname{EXR}(-1))$ & $\begin{array}{l}-0.0439 \\
(0.8739)\end{array}$ \\
\hline & & CoinEq(-1) & $\begin{array}{l}-0.0895 \\
(0.0000)\end{array}$ \\
\hline
\end{tabular}

Source: estimation by the author with E-views 9 using data extracted from the World Bank.

Note: values in the parenthesis shows the respective probability values for the level of significance.

This table illustrate that the one unit increase in gross domestic product with lag two have negative impact on foreign direct investment. In lag three the one unit increase negative impact on dependent variable and statistically significant. Foreign direct investment has positive impact and significant in lag two and three. Inflation rate with lag one positive impact on foreign direct investment. Trade openness is one unit increase in and positive impact on dependent variable. One unit increase in trade openness and negative impact on dependent variable. The value of 
Coint-Eq (-1) factor are -0.43541 statistically significant and negative of the factors shows to it will converge toward long run equilibrium. The coefficient of financial development (FD4) is positive impact and no significant. In lag one the one unit increase in financial development (FD4) and have positive impact on dependent variable. In labor force one unit increase in dependent variable and positive impact on gross domestic product. One unit increase in labor force with lag two and positive impact on gross domestic product. The coefficient of manufacturing with lag one the one unit increase and have positive impact on dependent variable. One unit increase in manufacturing by lag two and have positive impact and do not significant. The coefficient of exchange rate is one unit increase and have positive impact but not significant. One unit increase in exchange rate by lag one and have negative impact on gross domestic product. The factor of the Coint Eq (-1) coefficient is -0.685 also negative sign of the factor explain to it will converge in extra six month. The essential sculpt exists in short-run.

\section{Diagnostic Analysis of Models}

This part display fitness of models diverse diagnostic technique has been applied to evaluate heteroskedasticity and auto-correlation models.

e) 5.7.1 Autocorrelation and hetroskedasicity diagnostic for model 1 Table 5.6 autocorrelation and heteroskedasticity for model 1

\begin{tabular}{lccc}
\hline \multicolumn{1}{c}{ Name of test } & F-statistics value & Probability \\
\hline Breush-Godfrey correlation LM test & Model 1 & 0.55317 & 0.8338 \\
Hetroskedasicity & & 0.76126 & 0.7110 \\
\hline & & & \\
\hline Breush - Godfrey correlation LM tı & 0.87753 & 0.4329 \\
Hetroskedasticity & 0.5754 & 0.8264 \\
\hline
\end{tabular}

Source: estimation by the author with E-views 9.

Note: values in the parenthesis shows the respective probability values for the level of significance.

The null hypothesis is that there is no serial correlation. In model one Probability aspect is 0.8338 that is higher is 0.05 so we do not reject null hypothesis. The probability displays that we cannot reject null hypothesis and serial correlation does not exist. In model two P-value is 0.4329 and value is superior than 0.05. We cannot cast-off null hypothesis. The P-value displays that we do not cast-off null hypothesis and not any serial correlation occur. These results are displays in table 5.6 alternative and null hypothesis. In model one that value of probability as table 5.6 illustration that we cannot reject null hypothesis. So, sequences do not strive from Heteroskedasticity. The P-value of model one is 0.7710 is greater than 0.05 so we do not reject null hypothesis and in model there exist heteroskedasticity. In model two P-value is 0.8264 so value is superior than 0.05 its shows that cannot cast-off null hypothesis and there is heteroskedasticity occur in it.

\section{Stability Analysis of Data}

The analysis displays that CUSUM stability and CUSUM (cumulative sum of square of recursive residuals) chart through among limits of $5 \%$ level of significant. 
f) Stability analysis for Model I

CUSUM

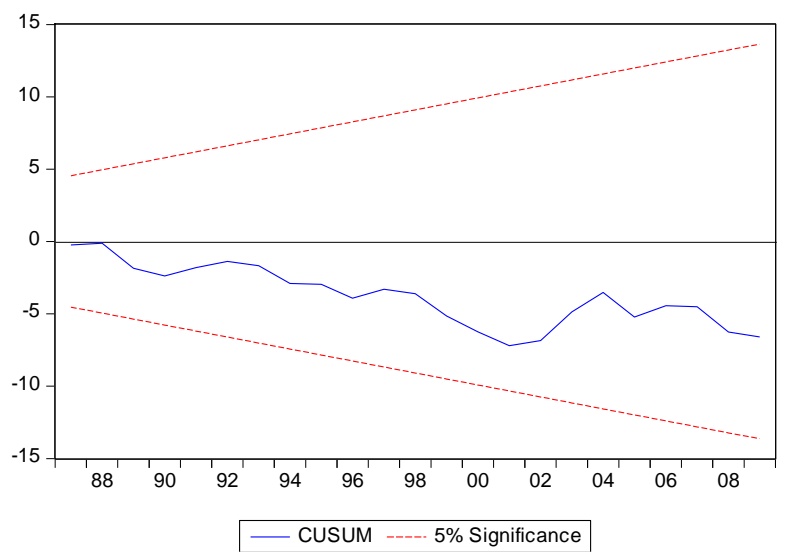

g) Stability Analysis for Model 2 CUSUM

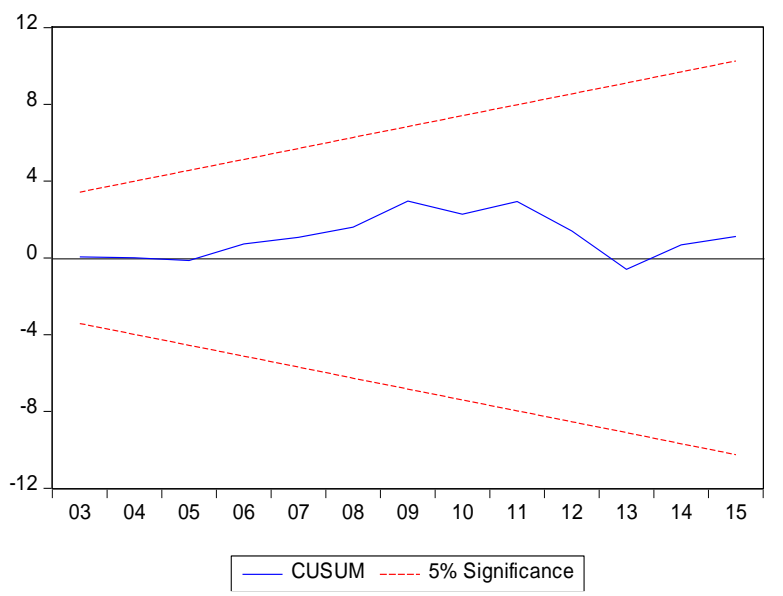

CUSUM SQUARE

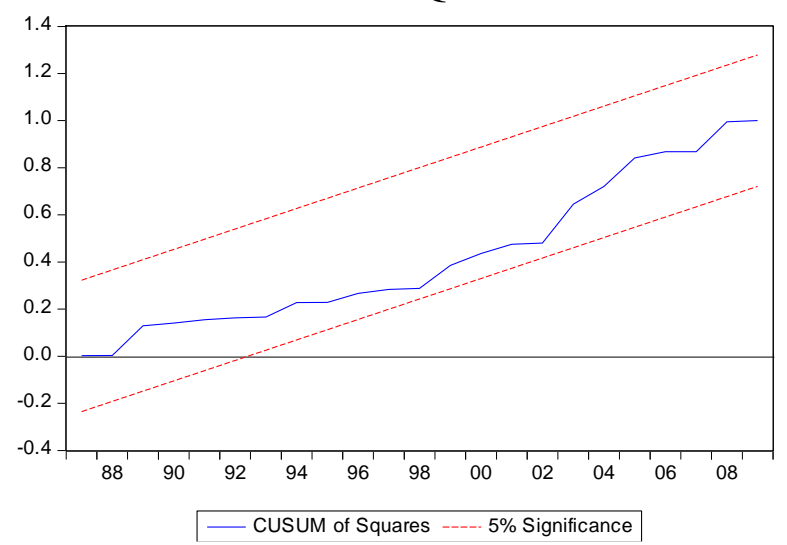

\section{CUSUM SQUARE}

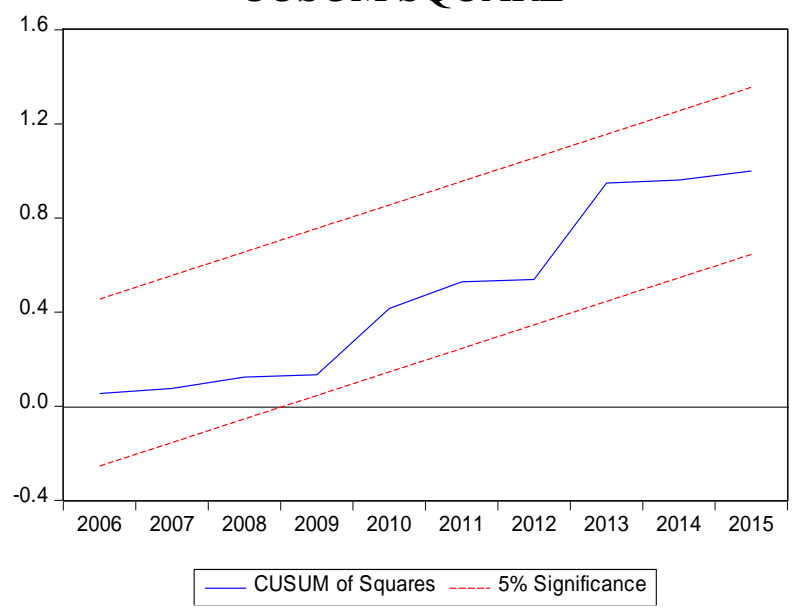

Source: evaluation through author with E-views 9.

In model one and model two both the graphs state that model is stable as CUSUM and CUSUMQ lies between critical limits.

\section{Conclusion and Policy Recommendation}

In underdeveloped countries and emergent economies, and nations in conversion stage have come progressively to understand FDI as a foundation of financial development and transformation, revenue generation and employment. States have opened their FDI administrations and followed other policies to entice investment. The issue of how best to pursue domestic strategies to exploit the benefits of FDI are better explored in the current analysis. The research of FDI for Expansion attempts principally to lighten the issue by focusing on the general consequence of FDI on macroeconomic growth and other welfare-enhancing processes, and on the channels through which these benefits take effect.in the study we have found a significant impact of FDI on Economic growth, furthermore, the development of the financial sector will enhance the overall economic growth in Pakistan. On the basis of the results it is recommended that the facilities may be provided to strengthen the domestic financial sector so that the FDI inflows can be attracted for economic growth.

\section{References}

Agrawal, G. (2015). Foreign direct investment and economic growth in BRICS economies: A panel data analysis. Journa

Ameer, W., Xu, H., \& Alotaish, M. S. M. (2017). Outward foreign direct investment and domestic investment: evidence from China. Economic research-Ekonomska istraživanja, 
30(1), 777-788.

Asia: panel cointegration and causality analysis. International Journal of Economics and

Bakari, S. (2017). The Impact of Domestic Investment on Economic Growth: New Policy Analysis from Algeria.

Falki, N. (2009). Impact of foreign direct investment on economic growth in Pakistan. International Review of Business Research Papers, 5(5), 110-120.

Finance, 8(1), 26.

Gao, J., Wei, Y. D., Chen, W., \& Chen, J. (2014). Economic transition and urban land expansion in Provincial China. Habitat International, 44, 461-473.

Hussain, M. E., \& Haque, M. (2016). Foreign direct investment, trade, and economic growth: An empirical analysis of Bangladesh. Economies, 4(2), 7.

Hussain, M. E., \& Haque, M. (2016). Foreign direct investment, trade, and economic growth: An empirical analysis of Bangladesh. Economies, 4(2), 7.

Hussain, M., Bashir, M. F., \& Shahzad, U. (2021). Do foreign direct investments help to bolster economic growth? New insights from Asian and Middle East economies. World Journal of Entrepreneurship, Management and Sustainable Development.

Ibrahim, M., \& Acquah, A. M. (2021). Re-examining the causal relationships among FDI, economic growth and financial sector development in Africa. International Review of Applied Economics, 35(1), 45-63.

Ilegbinosa, I. A., Micheal, A., \& Watson, S. I. (2015). Domestic investment and economic growth in Nigeria from 1970-2013: An econometric analysis. Canadian Social Science, 11(6), 70-79.

Liang, C., Shah, S. A., \& Bifei, T. (2021). The Role of FDI Inflow in Economic Growth: Evidence from Developing Countries. Journal of Advanced Research in Economics and Administrative Sciences, 2(1), 68-80.

Makuyana, G \& Odhiambo, N. M (2016). Public and private investment and economic growth in Zimbabwe: An empirical test, UNISA Economic Research Working Paper Series, WP 17/2016: $1-33$.

Osman Nuri, A. R. A. S., \& Oyegoke, E. O. Impact of Foreign Direct Investment on Economic Growth in Nigeria.

Solomon, E. M. (2017). Foreign direct investment, host country factors and economic growth. Ensayos Revista de Economía (Ensayos Journal of Economics), 30(1).l of Economics, Business and Management, 3(4), 421-424.

Sothan, S. (2015). Foreign direct investment, exports, and long-run economic growth in

Vernon, R. (1992). International investment and international trade in the product cycle. In International Economic Policies and their Theoretical Foundations (Second Edition) (pp. 415-435).

Zeb, N., Qiang, F., \& Rauf, S. (2013). Role of foreign direct investment in economic growth of Pakistan. International Journal of Economics and Finance, 6(1), 32. 